\title{
SOSIALISASI PEMANFAATAN PELEPAH SAWIT SEBAGAI ALTERNATIF PAKAN TERNAK SAPI DI DESA MULYOHARJO KECAMATAN BTS ULU KABUPATEN MUSI RAWAS
}

\author{
Merti Triyanti, Zico Fakhrur Rozi \\ Program Studi Pendidikan Biologi, STKIP PGRI Lubuklinggau \\ mertitriyanti28@gmal.com
}

\begin{abstract}
This Community Service Program is motivated by the large number of lands that have changed their function as both residential land and plantation land in Mulyoharjo, especially oil palm plantations. The plantations produce palm oil waste which is largely unused, including oil palm fronds. Also, these plantations' impact is the reduction in open land used by cattle farmers as animal feed. Therefore the STKIP PGRI Lubuklinggau PKM Team tried to apply palm fronds as an alternative to cattle feed. Palm fronds are one of the byproducts or can be said to be waste from oil palm plantations. The abundant amount of palm midrib can be used as animal feed. Palm midrib itself Has nutritional content that is $48.78 \%$ dry matter, crude protein $5.3 \%$, hemicellulose $21.1 \%$, cellulose $27.9 \%$, crude fiber $31.09 \%$, ash $4.48 \%$, BETN $51.87 \%$, lignin $16.9 \%$ and silica $0.6 \%$. This activity has been carried out by involving partners, namely the people of Mulyoharjo Village, and was followed with enthusiasm. The output targets to be achieved by the PKM team are the improvement of community values and publications. In practice, using theoretical and practical methods begins with the preparation, material, and practice of making cattle feed on palm fronds.
\end{abstract}

Keywords: Socialization, Palm midrib, Cow Feed, Mulyoharjo

\begin{abstract}
Abstrak
Program Pengabdian Kepada Masyarakat ini dilatarbelakangi oleh banyaknya lahan yang beralih fungsi baik sebagai lahan perumahan maupun sebagai lahan perkebunan yang ada di Desa Mulyoharjo terutama perkebunan sawit. Perkebunan tersebut menghasilkan limbah sawit yang sebagian besar tidak dimanfaatkan, diantaranya pelepah sawit. Selain itu, dampak dari perkebunan tersebut adalah berkurangnya lahan terbuka yang dimanfaatkan oleh peternak sapi sebagai pakan ternak. Oleh karena itu Tim PKM STKIP PGRI Lubuklinggau mencoba menerapkan pemanfaatan pelepah sawit sebagai alternatif pakan ternak sapi. Pelepah sawit merupakan salah satu hasil sampingan atau bisa dikatakan limbah dari perkebunan kelapa sawit. Pelepah Sawit yang cukup melimpah bisa dimanfaatkan sebagai Pakan Ternak. Pelepah Sawit sendiri Mempunyai kandungan nutrisi yaitu bahan kering 48,78\%, protein kasar 5,3\%, hemiselulosa 21,1\%, selulosa 27,9\%, serat kasar 31,09\%, abu 4,48\%, BETN 51,87\%, lignin $16,9 \%$ dan silika $0,6 \%$. Kegiatan ini telah dilaksanakan dengan melibatkan mitra yaitu masyarakat Desa Mulyoharjo dan diikuti dengan antusias. Target luaran yang ingin dicapai oleh tim PKM adalah perbaikan tata nilai masyarakat serta publikasi. Pada pelaksanaanya menggunakan metode teori dan praktek dimulai dengan tahap persiapan, pemberian materi serta praktek pembuatan pakan ternak sapi dari pelepah sawit
\end{abstract}

Kata kunci: Sosialisasi, Pelepah Sawit, Pakan Ternak Sapi, Mulyoharjo 


\section{PENDAHULUAN}

Perkebunan kelapa sawit sampai saat ini terus berkembang hampir di semua propinsi di Indonesia sehingga luasannya terus meningkat. Luas perkebunan kelapa sawit di Indonesia 3.300.000 ha (BPS, 2004). Salah satu produk limbah padat perkebunan kelapa sawit yang belum banyak dimanfaatkan sebagai pakan ternak adalah pelepah kelapa sawit. Produksi kelapa sawit ini terkonsentrasi pada satu kawasan dalam jumlah yang berlimpah dan tersedia sepanjang tahun (Sutardi, 1996) sehingga memiliki peluang yang besar sebagai pemasok bahan baku pakan. Pada saat panen tandan buah segar, 1 2 helai pelepah kelapa sawit dipotong dengan tujuan memperlancar penyerbukan dan mempermudah panen berikutnya. Produksi pelepah kelapa sawit yang telah berproduksi dapat mencapai 40 - 50 pelepah/pohon/tahun dengan bobot pelepah sebesar $4,5 \mathrm{~kg}$ berat kering per pelepah. Dalam satu hektar kelapa sawit diperkirakan dapat menghasilkan 6400 - 7500 pelepah per tahun, sehingga di Sumatera Utara dengan luasan perkebunan kelapa sawit 775.000 ha akan dapat menghasilkan 22.320.000 - 26.156.250 ton berat kering pelepah kelapa sawit per tahun.

Berkembangnya lahan

perkebunan sawit menyebabkan ketersediaan sumber pakan ternak semakin berkurang karena mempengaruhi jumlah rumputanrumputan yang ada akibat lahan terbuka digunakan untuk perumahan dan kecendrungan dari petani untuk menanam lahan dengan tanaman pertanian yang dapat bermanfaat langsung untuk kebutuhan manusia. Maka pemanfaatan limbah pertanian sebagai pakan alternatif adalah salah satu solusi untuk menanggulagi kekurangan pakan ternak ruminansia.
Salah satu produk samping tanaman perkebunan yang belum dimanfaatkan secara optimal adalah limbah perkebunan kelapa sawit. Tanaman perkebunan ini mempunyai potensi limbah yang dapat dimanfaatkan sebagai pakan ternak, baik unggas maupun ruminansia berupa daun, pelepah, tandan kosong, cangkang, serabut buah, batang, lumpur sawit, dan bungkil kelapa sawit. Limbah ini mengandung bahan kering, protein kasar dan serat kasar yang nilai nutrisinya dapat dimanfaatkan sebagai bahan dasar pakan ternak ruminansia (Mathius, dkk, 2003).

Pakan alternative yang tersedia dari kebun kelapa sawit diantaranya adalah pelepah dan daun kelapa sawit. Pada umumnya pelepah kelapa sawit dipanen sebelum buah dipanen. Hal ini dilakukan karena posisi tandan kelapa sawit berada pada celah-celah pelepah kelapa sawit. Dengan perkataan lain, bahwa jumlah pelepah yang diperoleh setiap hari oleh setiap pemanen akan sangat bergantung pada jumlah tandan buah segar (TBS) yang berhasil dipanen. Setiap harinya dapat diperoleh 50 -100 TBS. Dengan imbangan TBS dan pelepah yang dipanen setiap harinya maka jumlah pelepah yang berhasil dikumpulkan sejumlah 50 100 batang pelepah (Rokhman, 2004). Salah satu daerah yang memiliki perkebunan sawit adalah Desa Mulyoharjo Kecamatan BTS Ulu Kabupaten Musi Rawas. Berdasarkan hal tersebut, maka perlu dilakukan sosialisasi pemanfaatan pelepah sawit sebagai pakan ternak sapi di Desa Mulyoharjo

\section{METODE PELAKSANAAN}

Untuk mendukung tujuan kegiatan ini, tim pelaksana PkM membagi kegiatan menjadi tahap 
persiapan, tahap sosialisasi dan tahap pelatihan. Pada tahap persiapan dilakukan observasi ke lokasi dan koordinasi dengan mitra. Tahapan ini juga membagi tugas yang akan dilakukan oleh tim PKM. Selanjutnya, pada tahap sosialisasi yaitu pemberian materi kepada masyarakat. Tahap pelatihan dan pelaksanaan dilakukan kegiatan praktik pembuatan pakan ternak dari pelepah sawit yang didampingi oleh narasumber.

\section{HASIL DAN PEMBAHASAN}

Kegiatan pengabdian ini telah dilaksanakan pada bulan November 2019 dengan menggunakan metode praktek yang sebelumnya dilakukan pemberian materi oleh tim pengabdian kepada masyrakat yaitu dosen dari Prodi Pendidikan Biologi STKIP PGRI Lubuklinggau. Kegiatan pengabdian ini diikuti oleh masyarakat Desa Mulyoharjo Dusun V yang berjumlah 40 peserta. Kegiatan pengabdian kepada masyrakat ini dilatarbelakangi oleh banyaknya limbah sawit yang tidak dimanfaatkan oleh masyarakat Mulyoharjo yang sebagian besar telah mengalihfungsikan lahan untuk menanam tanaman sawit. Hal ini menyebabkan berkurangnya lahan kosong tempat tumbuhnya tanaman hijau yang digunakan oleh ternak sebagai bahan makanan. Dampak dari penanaman tanaman sawit menyebabkan banyaknya limbah sawit dan berkurangnya lahan tanaman hijau bagi ternak terutama dimusim kemarau. Solusi dari masalah tersebut adalah dengan memanfaatkan limbah sawit terutama pelepah sawit untuk digunakan sebagai alternatif pakan ternak sapi. Hal ini sesuai pendapat Hamdan (2004) yang menyatakan bahwa salah satu masalah yang dihadapi dalam pengembangan ternak sapi adalah kesulitan mendapatkan hijauan/pakan terutama diwilayah lahan kering khususnya pada musim kemarau.

Berdasarkan hasil observasi diketahui bahwa limbah dari tanaman sawit ini belum dimanfaatkan secara maksimal. Bahkan cenderung menjadi sampah yang menumpuk yang terkadang mengeluarkan bau tidak sedap. Menurut Mathius, dkk (2003), salah satu produk sampingan tanaman sawit yang belum dimanfaatkan secara optimal adalah pelepah sawit. Limbah ini mengandung bahan kering, protein kasar, dan serat kasar yang nutrisinya dapat dimanfaatkan sebagai bahan dasar pakan ternak ruminansia. Hal ini sesuai dengan pendapat Rokhman (2004) yaitu pakan alternatif yang tersedia dari kebun sawit adalah pelepah dan daun kelapa sawit. Pada umumnya, pelepah sawit dipanen sebelum buah dipanen. Hal ini dikarenakan posisi tandan kelapa sawit berada dicelah celah pelepah kelapa sawit.

Sedangkan menurut Hassan dan Ishida (1992), Potensi limbah pelepah dan daun sawit mencapai 40-50 pelepah/pohon/tahun). Kandungan zatzat nutrisi pelepah dan daun sawit adalah bahan kering 48,78\%, protein kasar 5,3\%, hemiselulosa 21,1\%, selulosa 27,9\%, serat kasar 31,09\%, abu 4,48\%, BETN 51,87\%, lignin 16,9\% dan silika 0,6\% (Imsya, 2007). Pendapat berbeda dikemukakan oleh Kandungan nutrien yang terdapat pada pelepah kelapa sawit seperti; bahan organik, serat deterjen netral sebesar 62 - $73 \%$ dan serat deterjen asam sebesar $31-42 \%$ relatif sebanding dengan zat nutrisi rumput. Meskipun kandungan protein kasar pelepah kelapa sawit $(4,7 \%)$ lebih rendah dibandingkan dengan protein kasar rumput $(10,07$ 13,87\%). Nilai kecernaan bahan kering pelepah kelapa sawit adalah 51\%, relatif sama dengan rumput alam yang 
mencapai 50 - 54\%. Berdasarkan kandungan nutrien dan nilai kecernaan pelepah kelapa sawit tersebut, maka energi pelepah kelapa sawit diperkirakan hanya mampu memenuhi kebutuhan hidup pokok, sehingga untuk pertumbuhan, bunting dan laktasi diperlukan pakan tambahan untuk memenuhi kebutuhan protein dan energi. Kandungan energi yang relatif sebanding antara rumput alam dengan pelepah kelapa sawit ini, menunjukkan bahwa pelepah kelapa sawit berpeluang untuk digunakan sebagai substitusi rumput dalam ransum pakan ruminansia.

\section{SIMPULAN}

Kegiatan pengabdian kepada masyarakat ini harapkan dapat memberikan wawasan dan pengetahuan kepada masyarakat Desa Mulyoharjo terutama peternak sapi. Sehingga dapat mengatasi limbah sawit yang berupa pelepah sawit menjadi alternatif pakan ternak sapi.

\section{UCAPAN TERIMAKASIH}

Ucapan terimakasih kepadaSTKIP PGRI Lubuklinggau yang telah mendanai Pengabdian Kepada Masyarakat ini melalui pendanaan Tahun 2019.

\section{DAFTAR PUSTAKA}

Badan Pusat Statistik. 2004. Statistik Indonesia. BPS Jakarta

Imsya, A. (2007). Konsentrasi Namonia, kecernaan bahan kering dan kecernaan bahan organik pelepah sawit hasil amoniasi secara in vitro. Prosiding Seminar Teknologi Peternakan dan Veteriner, 21 - 22Agustus 2007. Puslitbang Peternakan Badan Litbang Pertanian, Deptermen Pertanian Bogor. p. $111-115$.

Mathius I.W., D. Sitompul, B.P. Manurung, dan Azmi. 2004. Produk samping tanaman dan pengolahan kelapa sawit sebagai bahan pakan ternak sapi potong : suatu tinjauan. Hlm : 120-128. Prosiding Lokakarya Nasional Sistem Integrasi Kelapa Sawit-Sapi. Badan Penelitian dan Pengembangan Pertanian, Pemerintah Provinsi Bengkulu dan PT Agricinal

Mulyadi (2016). Pelepah Sait Sebagai Pakan Ternak. https://www.peternakankita.co m/pelepah-sawit-sebagaipakan-ternak-sapi/. Diakses tanggal 25 Oktober 2019.

Rokhman. 2004. Pelepah Kelapa Sawit sebagai Pakan Dasar Sapi. Prosiding Temu Teknis Nasional Tenaga Fungsional Pertanian Tahun 2004. Pusat Penelitian dan Pengembangan Peternakan 133. Badan Litbang Pertanian.

Sutardi, t.,dkk. 1996. Potensi limbah perkebunan sebagai bahan baku pakan ternak. Paper disampaikan pada pertemuan tingkat nasional: penggalian sumberdaya perkebunan untuk usaha peternakan. Medan 11 13 nopember. 